\title{
TwórCzość WitKaCEgo WObEC MIĘDZYWOJENNEJ KULTURY MASOWEJ
}

\author{
Katarzyna LisowsKa \\ kalisowska@wp.pl
}

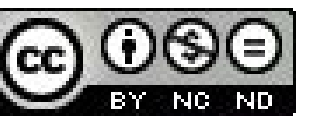

Stanisław Ignacy Witkiewicz, zarówno w pismach teoretycznych, jak i w twórczości artystycznej i literackiej, wyrażał niechęć do kultury masowej¹. Jednocześnie, w oryginalny sposób wykorzystywał zaczerpnięte z niej elementy. Warto zatem zapytać, co składa się na specyficzny stosunek Witkacego do tej dziedziny kultury. Odpowiedź wymaga odniesienia do różnych obszarów działalności autora - od prac filozoficznych począwszy, a na projektach scenariuszy filmowych skończywszy. Odwołam się zatem do rozmaitych form intelektualnej działalności S. I. Witkiewicza, mając świadomość, że poniższy tekst to jedynie wstępna propozycja ujęcia określonego w tytule zagadnienia.

Zacznijmy od odniesienia do estetyczno-aksjologicznych przekonań Witkacego. Jego filozofia opierała się na katastrofizmie, którego źródłem było między innymi uczestniczenie w roli świadka w Rewolucji Październikowej. Dla wychowanego w kulcie indywidualizmu młodzieńca konfrontacja z siłą tłumu stanowiła szokujące przeżycię2. Prawdopodobnie z tego doświadczenia wyniósł on przekonanie o rychłym nadejściu katastrofy, będącej wynikiem nieodwracalnego procesu historyczno-kulturowego i polegającej na zaniku zdolności do metafizycznych przeżyć. Powszechna uniformizacja, zmechanizowanie społeczeństwa i tłumienie wszelkich objawów jednostkowej twórczości miały doprowadzić do degeneracji kultury ${ }^{3}$ i całkowitego wyczerpania trzech kluczowych dziedzin umysłowej działalności człowieka, czyli sztuki, religii i przede wszystkim filozofii.

To właśnie eliminowanie filozofii z naszego życia intelektualnego było, zdaniem Witkacego, podstawową przyczyna, a zarazem przejawem obniżania się poziomu kultury. Miejsce spójnych, wywiedzionych z niemieckiej tradycji, systemów światopoglądowych, zajęła "francuska lekkość stylu i myślenia"4. Przeciętny członek społeczeństwa przestał interesować się prowadzonymi przez teoretyków sporami, a literaci, którzy powinni być umysłowymi przedstawicielami narodu, wcale nie dążyli do zmiany istniejącego stanu rzeczy5.

\footnotetext{
Kulturę masową rozumiem jako zespół norm, wzorów, praktyk itp. charakterystycznych dla zurbanizowanego i zindustrializowanego społeczeństwa. Zasięg tego pojęcia przyjęło się ograniczać do ostatnich dwustu lat historii kultury. Por. K. Dmitriuk, Kultura masowa, [w:] T. Żabski (red.), Stownik literatury popularnej, Wrocław 2006, s. 288. Za Antoniną Kłoskowską za wyznaczniki tego zjawiska przyjmuję: upowszechnienie się środków masowego przekazu, umożliwiających szeroki zasięg zestandaryzowanych treści kultury (kryterium ilości i standaryzacji), a także sformalizowanie i urzeczowienie dróg ich przekazywania. A. Kłoskowska, Kultura masowa. Krytyka i obrona, Warszawa 1980, s. 96, 98 i 99. Dodajmy, że w tego typu kulturze treści traktowane sa jako atrakcyjne widowisko. M. Golka, Socjologia kultury, Warszawa 2007, s. 152. Z kolei dzieło sztuki powinno być przystępne, tzn. „zrozumiałe dla przeciętnego, niewyrobionego odbiorcy” $\mathrm{i}$,przeznaczone do łatwej konsumpcji nie tylko za pierwszym razem, ale też przy każdym kolejnym spotkaniu". N. Carroll, Filozofia sztuki masowej, Gdańsk 2011, s. 194.

2 Por. K. Taras, Witkacy i film, Warszawa 2005, s. 131.

3 Por. J. Kwiatkowski, Dwudziestolecie międzywojenne, Warszawa 2008, s. 280.

4 J. Degler, Witkacy nieznany, [w:] S. I. Witkiewicz, Bez kompromisu. Pisma krytyczne i publicystyczne, Warszawa 1976, s. 19.

5 "Ludzie (...) szukają schronienia przed pospolitością i grozą życia w religii, teozofii, nawet nauce - tylko nie starają się znaleźć sensu jego w poznaniu nieubłaganych praw Istnienia w ogóle w filozofii: dlatego, że filozofia wymaga umysłowej pracy, a nie jest tylko dowiadywaniem się faktów, w które ma się uwierzyć, wymaga pewnej współtwórczości, wewnętrznego napięcia, wysiłku intelektu, do którego nie każdy jest zdolny, a raczej się za niezdolnego dla wygody uważa, to znaczy: zasadniczo zdolnym jest, ale w systematycznym umysłowym zapuszczeniu (...), w którym znajduje
} 
Szczególną uwagę Witkacy poświęcał bowiem artystom słowa - pisarzom, dziennikarzom i krytykom, obwinianym za obniżanie poziomu kultury umysłowej. Zamiast dbać o jakość swoich dokonań, starali się oni schlebiać gustom szerokiej publiczności (,(...) dziś młody bubek pełza na brzuchu przed rozwaloną bezczelnie klępą-publiką $\left.(. . .)^{\prime \prime 6}\right)$, dostosowując się do możliwości przeciętnego odbiorcy („Nasze pisma starannie dbają o to, aby poziom ich intelektualny nie podniósł się zbyt wysoko, bo ucierpiałaby na tym ilość prenumeratorów. W ten sposób -i pisma, i teatry, i książki zjeżdżają coraz niżej, przystosowując się do coraz niższych potrzeb, które dalej w tym wymiarze niskości stwarzają"7). Skutkowało to kształtowaniem się, wyzbytej z wszelkiej oryginalności „artystycznej i literackiej pseudokultury” („,Rzucają się [pasożyci literatury] na nią [na książkę], trawia, często niedokładnie, i oddają to potem zaprawione własnym sosem, nie zawsze pierwszej jakości"8). S. I. Witkiewicz był szczególnie niezadowolony z działalności „Wiadomości Literackich”, przeciwko którym prowadził publicystyczną kampanię. Piętnował między innymi, widoczna, jego zdaniem, zwłaszcza w felietonach i recenzjach Antoniego Słonimskiego i Jana Lechonia9, obecną w piśmie „kulturę dowcipiarstwa” („Dowcip jest rzeczą cenną w miarę. Ale gdy się go zacznie propagowaćjako jedną z najwyższych, jeśli nie najwyższą wartość literatury, poezji i sceny, jest obawa, że nastąpi generalne spłycenie tych dziedzin" ${ }^{10}$.

S. I. Witkiewicz rozumiał wprawdzie, że warunki życia ówczesnego społeczeństwa wpływały na niechęć odbiorców do rozrywek intelektualnych. Pochłonięty pracą zarobkową człowiek, w wolnym czasie szukał przede wszystkim relaksu („Wiem, że to utrzymywanie się w intelektualnej formie jest rzeczą niesłychanie trudna, o ile jest się zmęczonym innymi zajęciami. Wtedy wydaje się szczęściem kino, radio lub choćby książka Wallace'a i spać, spać jak najprędzej”11). Podobnie chwile wytchnienia zmuszonych "pracować nieistotnie, zarobkowo” literatów wypełniły „obowiązki towarzyskie, kawiarnie, bridge czy inna jaka cholera"12. Niewłaściwe pojmowanie wypoczynku, stanowiło jednak poważne zaniedbanie ze strony twórców i odbiorców kultury, którzy zamiast ambitnych zajęć wybierali ,"godziwe rozrywki" ${ }^{\prime 13}$ : radio, dancing, kino, gazetę (, z dnia na dzień i zastępującą niektórym wszelką inną lekturę"), widowiska sportowe, alkohol, nikotynę̨ ${ }^{14}$, bridge i „,rozmowę w kawiarni przy ogłuszającym jazzbandzie"15. Warto także zwrócić uwagę na dostrzeganą przez Witkacego niekorzystną zależność między pisarzami a publicznością (, Ciagłe obniżanie poziomu artykułów, książek i teatru do gustu danego przekroju społecznego doprowadza do tego, że wychowuje się coraz niższej wartości pokolenia, do których poziomu znowu trzeba się obniżać i w ten sposób dojdzie się do społeczeństwa kretynów”116).

się przeciętny Polak i jego domniemany oświeciciel: polski literat - traci człowiek beznadziejnie możność powrotu do tych rzeczy". S. I. Witkiewicz, O znaczeniu intelektualizmu w literaturze, [w:] tenże, Bez kompromisu..., dz. cyt., s. 282.

6 Tenże, Znowu to samo aż do znudzenia, czyli o roli światopogladu w literaturze, [w:] tenże, Bez kompromisu..., dz. cyt., s. 324.

7 Tenże, O znaczeniu intelektualizmu..., dz. cyt., s. 286.

8 Tenże, O artystycznej i literackiej pseudokulturze, [w:] tenże, Bez kompromisu..., dz. cyt., s. 201, 205.

9 Tamże, s. 206.

10 Tenże, Znowu to samo..., dz. cyt., s. 312.

11 Tenże, O znaczeniu filozofii dla literatury, [w:] tenże, Bez kompromisu..., dz. cyt., s. 249.

12 Tamże.

13 Tenże, O znaczeniu intelektualizmu..., dz. cyt., s. 282.

14 Tenże, Narkotyki. Niemyte dusze, Warszawa 1975, s. 177, 363. Interesujący wydaje się zwłaszcza stosunek Witkacego do radia. Było ono zagrożeniem dla wysokiej kultury muzycznej, ponieważ, popularyzując muzykę, musiało „,obniżyć jej ogólny poziom”, a poza tym „zmysłowy rozgwar muzyczny” uniemożliwiał „prawdziwe umysłowe skupienie”. Tamże, s. 361.

15 Tenże, O znaczeniu intelektualizmu..., dz. cyt., s. 283.

16 Tenże, Narkotyki..., dz. cyt., s. 176. 
Mimo tego S. I. Witkiewicz, choć był przekonany o zbliżających się nieuchronnie degeneracji człowieczeństwa i zaniku wyższych wartości, idealistycznie postulował walkę o ratowanie kultury. Wiele miało zależeć od indywidualnych wysiłków uczestników życia kulturalnego, którzy po dniu pracy powinni wykazać się „,bohaterstwem ponad siły” i znaleźć czas na ambitne zajęcia (,(...) to bohaterstwo musi być spełnione, o ile nasza literatura i krytyka nie mają zejść na kompletne psy"17). Poza tym zadaniem, niestety nielicznych, inteligentów miało być propagowanie filozoficznego myślenia, traktowanego jako jedyne źródło ochrony przed całkowitym antyintelektualizmem („Wydanie słownika filozoficznego i przetłumaczenie głównych prac zasadniczych kierunków filozofii jest według mnie pierwszym obowiązkiem ludzi nie chcących [!], aby za lat dwadzieścia lub trzydzieści uznano nas za bandę skretyniałych wesołków ${ }^{\prime \prime 18}$ ). Rację ma zatem Janusz Degler, gdy stwierdza, że Witkacy, wbrew wszelkim deklaracjom, wierzył w kulturotwórczą moc sztuki, a swoje zadanie widział między innymi w demaskowaniu niebezpieczeństw mechanizacji i w wychowywaniu rodaków ${ }^{19}$.

Stosunek S. I. Witkiewicza do kultury masowej okaże się jeszcze bardziej skomplikowany, gdy z płaszczyzny teorii przejdziemy na płaszczyznę twórczości. Autor wykorzystywał bowiem wiele wątków zaczerpniętych z tej dziedziny i przetwarzał je w oryginalny sposób. Proponuję, aby przeanalizować pod tym kątem te dokonania Witkacego, które niejako ze swej natury sytuują się na granicy dwóch obiegów kulturalnych - wysokiego i niskiego ${ }^{20}$. Będą nas interesowały: malarstwo portretowe, fotografia i film.

Jeśli chodzi o założoną w 1925 r. Firmę Portretowa, to jej działalność bywa rozmaicie interpretowana przez badaczy. Porównywano ją m.in. z gestem porzucenia sztuki przez Arthura Rimbauda i Marcela Duchampa ${ }^{21}$. Doszukiwano się też związków z opowiadaniem Romana Jaworskiego pt. Trzecia godzina, którego bohater zamienił uprawianie „czystej” twórczości na „stosowaną". Za zbieżność uważano zwłaszcza opisaną $\mathrm{w}$ tekście metodę podziału „prac" ${ }^{\prime 22}$ na kila typów ${ }^{23}$. Wydaje się jednak, że o założeniu Firmy rozstrzygnął czynnik ekonomiczny - Witkacy miał kłopoty finansowe i potrzebował w miarę stabilnego źródła dochodów $w^{24}$. Ze względu na użytkowy charakter i konieczność uwzględniania gustów odbiorców („Pracując zarobkowo byłem zmuszony ostatnio malować portrety i zawierać kompromisy z upodobaniami, co oddaliło mnie od prawdziwego malarstwa" ${ }^{\prime 25}$ ), autor nie uznawał nawet tego zajęcia za działalność artystyczną.

Co więcej, Regulamin Firmy Portretowej „,S. I. Witkiewicz” mógł kojarzyć się z podobną instrukcją „obowiązującą" gości kawiarni „Pod Pikadorem"26. Analogia ze Skamandrytami, których ludyczna twórczość była obca założeniom estetyki S. I. Witkiewicza, świadczy o komercyjnym i kompromisowym charakterze działalności Firmy. Mimo tego, Witkacy pragnął połączyć pracę zarobkową z uprawianiem sztuki. Dlatego, choć oczywiście w Regulaminie znalazły się zasady normujące sposób zawierania „, transakcji handlowych” z klientami („Umowa na raty lub

17 Tamże, s. 284

18 Tenże, Znowu to samo..., dz. cyt., s. 321.

19 J. Degler, Witkacy..., dz. cyt., s. 15 i 21.

20 Posługuję się tym rozróżnieniem ze względu na zakorzenioną w modernizmie świadomość kulturową Witkacego. W analizie współczesnych nam zjawisk kulturalnych ów dychotomiczny podział byłby oczywiście zbyt dużym uproszczeniem.

${ }_{21}$ Por. B. Zgodzińska-Wojciechowska, A. Żakiewicz, Witkacy - Stanisław Ignacy Witkiewicz, Warszawa 2001, s. 18.

22 Trzeba jednak dodać, że „pracami” były aranżowane przez bohatera pogrzeby.

23 Por. B. Zgodzińska-Wojciechowska, A. Żakiewicz, dz. cyt., s. 19-20.

24 Tamże, s. 18.

25 S. I. Witkiewicz, wywiad dla pisma „Nasz przegląd” 04.1926, [w:] tenże, Bez kompromisu..., dz. cyt., s. 520.

${ }_{26}$ Zob. B. Zgodzińska-Wojciechowska, A Żakiewicz, dz. cyt., s. 20. 
na weksle nie jest wykluczona"; ,Portrety kobiece z obnażonymi szyjami są o jedną trzecią droższe. Każda ręka kosztuje jedną trzecią ceny. Co do portretów z rękami lub w całej figurze - umowy specjalne" ${ }^{\prime 27}$ ), a także zgoda na posługiwanie się reklamą („Przesyłanie przez firmę dawnym klientom zawiadomień o jej przybyciu do dawnego miejsca, nie ma na celu wymuszania na nich nowych portretów, tylko ułatwia zamówienie tychże tym znajomym klientów, którzy na podstawie widzianych prac mieliby ochotę na coś podobnego"28), to malarz nadal dbał o swobodę twórcza, zastrzegając sobie prawo do wyboru techniki i sposobu malowania („Firma zastrzega sobie prawo do rysowania bez świadków"; „Technika jest mieszaniną węgla, kredek, ołówka i pastelu"29) i żądając szacunku dla efektu swojej pracy (,„Klient nie ma prawa żądać zniszczenia portretu"; , ,Wykluczona jest absolutnie wszelka krytyka ze strony klienta"30).

Portret stanowił bowiem skończone dzieło, całkowicie zależne od inwencji autora (,Wszelkie uwagi techniczne są wykluczone, jak również żądanie poprawek" ${ }^{\prime \prime 1} 1$. Poza tym, aby jeszcze silniej połączyć cele artystyczne z komercyjnymi, S. I. Witkiewicz podzielił oferowane obrazy na kilka precyzyjnie określonych typów ${ }^{32} \mathrm{i}$ każdemu z nich przyznał odrębną cenę. Wyjątkiem był zarezerwowany dla przyjaciół Typ $\mathrm{C}^{33}$, który odróżniał się od pozostałych wyraźnymi nawiązaniami do założeń Czystej Formy.

Warto też dodać, że, zdaniem niektórych badaczy, cechą właściwą wielu portretom Witkacego było zastosowanie środków artystycznych zaczerpniętych z fotografii34. To kolejny, wymagający analizy, obszar działalności autora. On sam nie uważał zdjęć za prawdziwą sztukę, ponieważ były one pozbawione wewnętrznej konstrukcji, a ich istota polegała na naśladowywaniu przypadkowych elementów rzeczywistości ${ }^{35}$. Wspominał o tej dziedzinie zazwyczaj w odniesieniu do realistycznego malarstwa (,(...) wolę patrzeć na kolorową fotografię niż na najbardziej doskonałe trompe l'oeil w malarstwie (... $)^{\prime \prime 36}$ ). Mimo tego, zapewne pod wpływem ojca, fotografował od wczesnej młodości. Najwcześniejsze lata (1899-1905) zaowocowały głównie pejzażami, których miejsce zajęły później portrety ${ }^{37}$.

Zdaniem autorek pracy poświęconej fotografii S. I. Witkiewicza, po 1918 r. zdjęcia stały się elementem "teatru życia" artysty ${ }^{38}$. Wywołane klisze miały utrwalać miny i zmiany strojów Witkacego $^{39}$, a także scenki improwizowane wspólnie ze znajomymi ${ }^{40}$. Aparat prowokował do gry ${ }^{41}$, pobudzającej aktorskie umiejętności S. I. Witkiewicza. Z relacji bliskich mu osób wiemy, że nie był on ich pozbawiony. Parodiował znajome lub sławne postacie (np. Karola Szymanowskiego czy Andrzeja Struga) i urządzał spontaniczne wystąpienia połączone ze śpiewem, i grą na pia-

\footnotetext{
27 S. I. Witkiewicz, Regulamin Firmy Portretowej „S. I. Witkiewicz”, [w:] tenże, Bez kompromisu..., dz. cyt., s. $34-35$.

28 Tamże, s. 35.

29 Tamże, s. 34.

30 Tamże.

31 Tamże.

32 Por. np. Typ A: „Wykonanie »gładkie«, z pewnym zatraceniem charakteru na korzyść upiększenie, względnie zaakcentowania »ładności«”. Typ C: „Charakterystyka modela subiektywna- spotęgowania karykaturalne tak formalne, jaki i psychologiczne nie wykluczone [!]. W granicy kompozycja abstrakcyjna, czyli tzw. »Czysta Forma«". Tamże, s. 33.

33 B. Zgodzińska-Wojciechowska, A. Żakiewicz, dz. cyt., s. 21.

34 Por. E. Franczak, S. Okołowicz, Przeciw Nicości. Fotografie Stanisława Ignacego Witkiewicza, Kraków 1986, s. 18.

Por. tamże, s. 21.

36 S. I. Witkiewicz, 622 Upadki Bunga, czyli Demoniczna Kobieta, Kraków 2005, s. 97.

37 E. Franczak, S. Okołowicz, dz. cyt., s. 13

38 Tamże, s. 24.

39 Tamże, s. 29.

40 Tamże, s. 31.

41 Tamże, s. 33.
} 
ninie $^{42}$. Zdarzało się, że temu „teatrzykowi” towarzyszył aparat. Poza tym rozrywkowe traktowanie fotografii pozwalało nasycać ją pierwiastkami kultury masowej. Witkacy, niczym gwiazda srebrnego ekranu, organizował dla siebie sesje u cenionych profesjonalistów, m.in. u Janiny Kępinskiej oraz Mariana i Witolda Dederków $w^{43}$ i wcielał się w bohaterów dobrze znanych szerokiemu gronu odbiorców. Dzisiaj możemy go oglądać w rolach: kowboja, bandyty, wampira, „wujcia z Kalifornii”, Rudolfa Valentino, Dra Jekylla, Mr Hyde'a, „nieznanego aktora kinowego Carfaldo Ricci”, ,potwora z Düsseldorfu”, „Lorda Fitzpura na regatach w Southampton” czy Majakowskiego z filmu Chuligan i panna.

Z deklarowaną pobłażliwością często jednak kontrastowała artystyczna praktyka. Za przykład niech posłuży jedno z najbardziej znanych zdjęć S. I. Witkiewicza, czyli Autoportret wielokrotny $w$ lustrach. Jego genezy upatrywano bądź w krótkometrażowym filmie Bustera Keatona The Play House (1921 r.), bądź w dziewiętnastowiecznej powieści posługującej się motywem sobowtóra (por. m.in. twórczość Roberta Louise'a Stevensona, Ernsta Theodora Amadeusa Hofmanna), ale wśród hipotetycznych odniesień wymieniano także m.in. prace Marcela Duchampa i futurysty Umberto Boccioniego oraz powieść Hermana Hessego pt. Wilk stepowy ${ }^{44}$. Witkacy bowiem świadomie wykorzystywał możliwości fotografii, tylko pozornie lekceważąc możliwości tej dziedziny sztuki ${ }^{45}$. Łącząc doświadczenie własne i znawców (np. Józefa Głogowskiego i Władysława Jana Grabskiego), działał jak aktor inspirowany przez filozofa i eksperymentatora. Każde zdjęcie traktował jako zamkniętą całość, dlatego tak dużą rolę w ich interpretacji odgrywały, niestety nie zawsze zachowane, tytuły i dopiski ${ }^{46}$.

Dzisiaj ten obszar twórczości Witkacego, przez niego samego marginalizowany, jest bardzo ceniony przez znawców. We wczesnych pracach dostrzeżono m.in. nowatorską kompozycję, dobre wykorzystanie światła oraz zastosowanie w portretach ciasnego kadru, eksponującego psychikę postaci (efekt ten upowszechnił się dopiero w latach dwudziestych XX wieku) ${ }^{47}$. Natomiast późniejsze fotografie uznano za prekursorskie w programowym rejestrowaniu manifestów osobowości artysty ${ }^{48}$.

Jak już wspomniałam, S. I. Witkiewicz, podczas studyjnych sesji, często wcielał się w postacie znane ówczesnym odbiorcom ze srebrnego ekranu. J. Degler poszczególne serie zdjęć nazywa wręcz „,krótkimi »filmikami «" ${ }^{\prime 49}$. A jak sam autor odnosił się do tak istotnego obszaru kultury masowej, jak kino?

W wypowiedziach teoretycznych i publicystycznych oceniał je bardzo negatywnie. Przede wszystkim uważał, że film „,sztuką nie jest i być nie może, wbrew wszystkim naciaganiom jego teoretyków i dociąganiem go do fikcyjnej dziesiątej muzy, która, na szczęście, nie będzie nigdy $(. . .)^{\prime \prime 50}$. W tego typu dziele nie mogą zrealizować się założenia Czystej Sztuki, ponieważ, jako wynik procesu technicznego i pracy zbiorowej nie stanowi ono wyrazu , jedności osobowości” twórcy, a nastawienie na reprodukowanie rzeczywistości nie pozwala mu wywoływać uczuć metafizycznych ${ }^{51}$.

\footnotetext{
42 Tamże, s. 32.

43 Tamże, s. 33.

44 Por. tamże, s. 27.

45 Por. tamże, s. 24.

46 Por. tamże, s. 35.

47 Tamże, s. 19.

48 Tamże, s. 37.

49 J. Degler, Witkacego portret wielokrotny. Szkice i materiaty do biografii (1918-1939), Warszawa 2009, s. 193.

50 S. I. Witkiewicz, Dzieła zebrane, t. 9: "Teatr" i inne pisma o teatrze, Warszawa 1995, s. 330-331.

51 J. Degler, Witkacego portret..., dz. cyt., s. 186.
} 
Co więcej, S. I. Witkiewicz uważał tę dziedzinę za niebezpieczną dla kultury wysokiej. Film, spełniając oczekiwania nowoczesnego, dynamicznego widza ${ }^{52}$, zagrażał przede wszystkim teatrowi („,Kinematograf może wszystko, cokolwiek dusza zapragnie (...) - i czyż warto się trudzić, produkując rzecz tak piekielnie trudna, jak sceniczna naprawdę sztuka teatralna, wobec tak groźnego rywala, jakim jest wszechwładne »kino «" $)^{53}$. Witkacy dostrzegał, że ówczesne kino stanowiło głównie rozrywkę dostosowaną poziomem do przeciętności tłumu ${ }^{54}$. Od początku fabuła dominowała nad formą ${ }^{55}$, a lata trzydzieste to okres wielkiej popularności farsy komedioweje operetkę $\mathrm{i}$ kabaret5 ${ }^{57}$. Film był zatem przejawem narastającej masowości sztuki i razem z dancingiem, widowiskami sportowymi, radiem i prasą należał do „bożków karmiących się korą mózgową" ${ }^{\prime 58}$.

Jednak głębsza analiza ujawnia kolejny paradoks Witkacowskiego stosunku do rozmaitych przejawów kultury masowej. Otóż, wbrew oficjalnie głoszonej niechęci do kina, S. I. Witkiewicz cenił nie tylko dokonania niemieckich ekspresjonistów, zwłaszcza Gabinet doktora Caligari, ale też rysunkowe produkcje Walta Disneya. Miał również swoich ulubionych aktorów: Gretę Garbo, Rudolfa Valentino, Dorothy Lamour, Gary'ego Coopera, Bustera Keatona, Charliego Chaplina i Harry'ego Langdona. Nie bez powodu więc Jadwiga Witkiewiczowa nazwała męża „wielkim amatorem kina”, zaznaczając, że często chodzili razem na seanse, po których pisarz naśladował, utrwalane potem na zdjęciach, postacie ${ }^{59}$.

Poza tym, według relacji żony, marzył on o wystąpieniu w filmie. Pierwsza konfrontacja z kamerą miała miejsce na spotkaniu u Augusta Zamoyskiego. Gospodarz przywiózł z Paryża aparat filmowy, a Witkiewiczowie zaimprowizowali scenę uwodzenia ${ }^{60}$. Poważniejszą szansą była propozycja reżysera Ryszarda Ordyńskiego, który chciał, by Witkacy wcielił się w jedną $\mathrm{z}$ postaci występujących $\mathrm{w}$ przygotowywanym przez niego filmie literackim ${ }^{61}$. Pisarz wiązał z tym przedsięwzięciem duże nadzieje, dlatego wziął udział w pierwszych zdjęciach. Zofia Stryjeńska, będąca świadkiem kręcenia jednej ze scen, stwierdziła, że posiadał on „,wszelkie dane na gwiazdę". Jednak S. I. Witkiewicz bardzo szybko zrezygnował ze współpracy, ponieważ, prawdopodobnie, zniechęcił go powolny tryb pracy ${ }^{62}$.

Trzeba też wspomnieć o innych możliwych przyczynach zainteresowania, jakim autor darzył kino. Zaangażowanie się $\mathrm{w}$ ten rodzaj twórczości stwarzało kolejną szansę na uwolnienie się od kłopotów finansowych. W chwilach frustracji Witkacy planował wręcz porzucenie dramatopisarstwa na rzecz układania scenariuszy i odgrywania ich z grupą przyjaciót, ale nigdy nie zrealizował tego projektu. Pisał o tym w jednym z listów: „Ja (o ile mnie nie pokręci) zdecydowałem się plunać na teatr jako na zarobek i grać też w kino. Będziemy grać razem z Langierem i pisać filmy dla różnych dam. Co ty na to?"'63.

52 Zob. K. Taras, dz. cyt., 93.

53 S. I. Witkiewicz, Dzieła zabrane, t. 8: Nowe formy w malarstwie i wynikajace stąd nieporozumienia. Szkice estetyczne, Warszawa 2002, s. 205.

54 Por. B. Armatys, L. Armatys, W. Stradomski (red.), Historia filmu polskiego, t. 2, Warszawa 1988, s. 52.

55 W. Banaszkiewicz, W. Witczak (red.), Historia filmu polskiego, t. 1, Warszawa 1966, s. 150-151.

56 B. Armatys, L. Armatys, W. Stradomski (red.), dz. cyt., s. 304.

57 Tamże, s. 127.

58 Zob. J. Degler, Witkacego portret..., dz. cyt., s. 187.

59 Tamże, s. 187-188.

60 Tamże, s. 189.

61 Witkiewicz miał zagrać profesora Piotra Głowińskiego, a film był adaptacją powieści Andrzeja Struga pt. Mogiła nieznanego żotnierza. Zob. tamże, s. 189-190.

62 Tamże, s. 192.

63 S. I. Witkiewicz, Całuję Was gdzie chcecie. Listy do Leona i Wtadysławy Reynelów, z rękopisu podała do druku i opracowała M. Gamdzyk-Kluźniak, [b.m.w.], list z 25 VI 1922, [cyt. za]: tamże, s. 189.

OgRody NAUK I SZTUK NR 2012 (2) 
Mimo tego, wpływy filmu są widoczne w twórczości literackiej S. I. Witkiewicza - zarówno w powieści, jak i w dramacie. Katarzyna Taras zauważa w jego beletrystyce wiele cech "filmowej wyobraźni” ${ }^{\prime 1}$ m.in.: stosowanie „dynamicznego szczegółu” zamiast „epickiej rozlewności”, voyeuryzm, posługiwanie się pojęciami ze sztuki filmowej², wizualnośc 3 i dobre operowanie świattem ${ }^{4}$. Elementy te niewątpliwie wzbogaciły prozę autora. Warto też wspomnieć o ciekawych przekształceniach takich chwytów kinowych, których pierwotnym zadaniem było schlebianie gustom masowego odbiorcy. Chodzi między innymi o nasycanie fabuły wątkami sensacyjnymi, umieszczanie akcji w atrakcyjnych „kinematograficznie” sceneriach ${ }^{5}$ a także prowokacyjność $c^{6}$ jaskrawość pewnych efektów.

Podobne zjawiska obserwujemy na płaszczyźnie dramatu. Zdaniem Tadeusza Nyczka sztuki tropikalne Witkacego (Metafizyka dwugłowego cieleccia, Bzik tropikalny, Niepodległość trójkatów) realizują model filmu „eegzotycznego", podobnego do cyklu przygód Indiany Jonesa ${ }^{7}$. Zacytujmy badacza: „»Boski i operetkowy« idiotyzm tych dramatów, gdzie na jednej stronie mieszają się polityka, farsa, miłość, rewolwerowe strzały, egzotyczne kochanki i twardzi kolonialiści o sentymentalnych duszach morskich piratów - czegóż więcej trzeba? Znajdzie się cośi d dla ambitnych: rodzący się młody, dziki kapitalizm, romantyczny i bezwzględny zarazem (...). Jednym słowem, każdy z tych dramatów jest wymarzonym scenariuszem do niezłego thrillera albo kryminału w stylu Hammetta czy Chandle$\mathrm{ra}^{\prime \prime}$. Z kolei Daniel Charles Gerould zwrócił uwagę na wykorzystanie wielu wysublimowanych filmowych efektów $\mathrm{w}$ dramatach, m.in. zapożyczenie $\mathrm{z}$ animowanej produkcji metody zmniejszania i powiększania bohatera (Gyubal Wahazar) $)^{9}$ oraz postugiwanie się „efektem reflektorowym”, czyli skupieniem światła na kilku postaciach (Metafizyka dwugłowego cieleccia, Wariat i zakonnica) ${ }^{10}$.

J. Degler zaś, podobnie jak T. Nyczek, dostrzegł podobieństwo wielu dramatów Witkiewicza do scenariuszy filmowych. Według badacza przykładowy scenariusz sztuki ze Wstępu do Teorii Czystej Formy $w$ teatrze przypomina "slapstickową komedyjkę", a analogia ta wynika z wykorzystania farsowych efektów właściwych komizmowi sytuacyjnemu burlesek filmowych ${ }^{11}$. Najwięcej odniesień do filmowych chwytów artystycznych znalazło się w Szalonej lokomotywie. Wbrew postulatowi odrzucenia realizmu w teatrze, Witkacy chciał, wystawiając tę sztukę, uzyskać pełny weryzm. Główny środek do tego celu, poza efektami akustycznymi i świetlnymi, miało stanowić umieszczenie w głębi sceny aparatu kinematograficznego. Wprowadzenie tego pomysłu w życie należałoby uznać za jedno z pierwszych w historii polskiej dramaturgii połączenie teatru z techniką filmową ${ }^{12}$.

Lektura powieści i dramatów Witkacego pozwala stwierdzić, że odwołania do „dziesiątej Muzy” dawały w obu dziedzinach bardzo dobre efekty, a autor, wbrew deklaracjom, doceniał wartość artystyczną twórczości filmowej, Jak zatem interpretować zasygnalizowaną rozbieżność między teorią a praktyką? Witkiewicz nie odróżniał nigdzie wyraźnie instytucji kina od sfery filmu, ale być może

1 K. Taras, dz. cyt., s. 62

2 Tamże, s. 31.

3 Tamże, s. 24

4 Tamże, s. 62.

5 Tamże, s. 57.

6 Tamże, s. 61.

7 Zob. J. Degler, Witkacego portret...., dz. cyt., s. 196.

8 T. Nyczek, Woody Allen, syn Witkacego, [w:] E. Chudziński (red.), Witkacy w teatrze końca wieku. Materiały z Sesji Witkacowskiej Kraków-Ochodza, 3-5 października 1991, Kraków 1992, s. 17, [cyt. za:] tamże.

9 D. C. Gerould, Stanisław Ignacy Witkiewicza jako pisarz, Warszawa 1981, s. 213.

10 Tamże, s. 205 i 295.

11 J. Degler, Witkacego portret..., dz. cyt., s. 195.

12 Tamże, s.193-194. Niewykluczone, że Witkacy słyszał o podejmowanych przez rosyjskich i włoskich twórców próbach wprowadzenia projekcji filmowych do teatru. Zob. tamże, s. 196. 
jego krytyka odnosiła się przede wszystkim do pierwszej z wymienionych dziedzin, niewątpliwie zakorzenionej w kulturze masowej. Natomiast film, choć podobnie jak powieść, nie należał do dziedziny sztuki, reprezentował pewne wartości, które warto było wykorzystać $\mathrm{w}$ istotnej twórczości ${ }^{13}$.

Tym, co łączy widoczne w twórczości Witkacego nawiązania do kultury masowej jest ich ludyczny charakter. Autor potrafił przetworzyć zapożyczone wątki w zabiegi o dużej wartości artystycznej. Ów eksperyment potwierdzał jednak jego przekonanie wyczerpywaniu się sztuki i łączył się z pesymistyczną refleksją dotyczącą stanu cywilizacji zachodniej. Czerpanie z kultury masowej współgrało zatem z głoszonym katastrofizmem i wpisywało się w całość projektu światopoglądowego Witkiewicza.

\section{LITERATURA PODMIOTU}

Witkiewicz S. I., 622 Upadki Bunga, czyli Demoniczna kobieta, Kraków 2005.

Witkiewicz S. I., Bez kompromisu. Pisma krytyczne i publicystyczne, oprac. J. Degler, Warszawa 1976.

Witkiewicz S. I., Dzieła zebrane, t. 8: Nowe formy w malarstwie i wynikajace stad nieporozumienia. Szkice estetyczne, oprac. J. Degler, L. Sokół, Warszawa 2002.

Witkiewicz S. I., Dzieła zebrane, t. 9: "Teatr" i inne pisma o teatrze, oprac. J. Degler, Warszawa 1995.

Witkiewicz S. I., Narkotyki. Niemyte dusze, oprac. A. Micińska, Warszawa 1975.

Witkiewicz S. I., O artystycznej i literackiej pseudokulturze, [w:] tenże, Bez kompromisu. Pisma krytyczne i publicystyczne, oprac. J. Degler, Warszawa 1976.

Witkiewicz S. I., O znaczeniu filozofii dla literatury, [w:] tenże, Bez kompromisu. Pisma krytyczne i publicystyczne, oprac. J. Degler, Warszawa 1976

Witkiewicz S. I., O znaczeniu intelektualizmu w literaturze, [w:] tenże, Bez kompromisu. Pisma krytyczne i publicystyczne, oprac. J. Degler, Warszawa 1976

Witkiewicz S. I., Znowu to samo aż do znudzenia, czyli o roli światopogladu w literaturze, [w:] tenże, Bez kompromisu. Pisma krytyczne i publicystyczne, oprac. J. Degler, Warszawa 1976.

\section{LITERATURA PRZEDMIOTU}

Armatys B., Armatys L., Stradomski W. (red.), Historia filmu polskiego, t. 2, Warszawa 1988.

Banaszkiewicz W., Witczak W. (red.), Historia filmu polskiego, t. 1, Warszawa 1966.

Carroll N., Filozofia sztuki masowej, przekł. M. Przylipiak, Gdańsk 2011

Degler J., Witkacego portret wielokrotny. Szkice i materiaty do biografii (1918-1939), Warszawa 2009.

Degler J., Witkacy nieznany, [w:] Witkiewicz S. I., Bez kompromisu. Pisma krytyczne i publicystyczne, oprac. J. Degler, Warszawa 1976

Dmitriuk K., Kultura masowa, [w:] Żabski T. (red.), Słownik literatury popularnej, Wrocław 2006.

Franczak E., Okołowicz S., Przeciw Nicości. Fotografie Stanisława Ignacego Witkiewicza, Kraków 1986.

Gerould D. C., Stanisław Ignacy Witkiewicz jako pisarz, Warszawa 1981.

Golka M., Socjologia kultury, Warszawa 2007.

Kłoskowska A., Kultura masowa. Krytyka i obrona, Warszawa 1980

Kwiatkowski J., Dwudziestolecie międzywojenne, Warszawa 2008.

Taras K., Witkacy i film, Warszawa 2005.

Zgodzińska-Wojciechowska B., Żakiewicz A., Witkacy - Stanisław Ignacy Witkiewicz, Warszawa 2001.

Żabski T. (red.), Słownik literatury popularnej, Wrocław 2006.

\section{STRESZCZenie}

W tekście zajęłam się relacjami między twórczością Stanisława Ignacego Witkiewicza a kulturą masową. Przeanalizowałam fotografie i malarstwo Witkacego, a także widoczne w jego dramatach i powieściach odwołania do sztuki filmowej. Celem było ukazanie niejednoznacznego stosunku autora do kulutry masowej.

13 Trzeba jednak zaznaczyć, że przyczyny wykluczenia filmu z dziedziny sztuki były odmienne od tych, które nie pozwoliły uznać powieści za sztukę.

OgRody NAUK I SZTUK NR 2012 (2) 
Nawiązałam też do filozoficznego światopoglądu Witkiewicza, dlatego odniosłam się do jego pism z dziedziny filozofii i teorii sztuki. Konieczne było także naszkicowanie sytuacji kultury masowej w międzywojennej Polsce. Wykorzystałam m.in. prace Janusza Deglera, Katarzyny Taras i Daniela C. Geroulda.

Słowa kluczowe: kultura masowa, katastrofizm, mechanizacja, intelektualizm, fotografia, pejzaż, portret, technika filmowa.

\section{Witkacy's Oeuvre and Mass Culture in the Interwar Period}

\section{Summary}

The aim of this paper is to consider the relationship between the work of S. I. Witkiewicz and mass culture. First, I analyse Witkacy's photography and paintings. Then, I focus on the connections between his dramas and novels, and cinematography. The idea is to reveal the author's ambiguous attitude towards mass culture.

I refer to Witkacy's philosophical and aesthetic writings. References to Polish mass culture of the interwar period are also included. The bibliographical basis of the study contains works of such authors as Janusz Degler, Katarzyna Taras and Daniel C. Gerould.

Key words: mass culture, catastrophism, mechanization, intellectualism, photography, landscape painting, portray, film technique. 